\title{
THE INFLUENCE OF FINANCIAL LITERATURE ON THE SPIRIT OF ENTREPRENEURSHIP ON STUDENTS OF ISLAMIC PRIMARY SCHOOL
}

\author{
Tri Ratna Dewi ${ }^{1}$ and Miftakhur Rohmah ${ }^{2 *}$ \\ ${ }^{1,2}$ Primary School Teacher Education Department, STKIP Nurul Huda Sukaraja, \\ East OKU, Indonesia \\ *Email: rohmah@stkipnurulhuda.co.id
}

\author{
Website: \\ https://jurnal.uinantasari.ac.id/index.php/adzka
}

Received: 25 October 2020; Accepted: 10 June 2021; Published: 23 June 2021

DOI: 10.18952 /aladzkapgmi.v11i1.4055

\begin{abstract}
The objectives of this study are 1) Knowing how to implement Financial Literacy education for children in MI East OKU. 2) Knowing how the entrepreneur spirit in children in MI East OKU. 3) Knowing how big the influence of financial literacy on the entrepreneur spirit of the children of MI East OKU. The method used is mixed methods. Qualitative methods are used to find the hypothesis, while quantitative methods are used to test research hypotheses. Sampling using purposive sampling technique by determining the criteria for financial literacy and entrepreneur spirit. The sample in this study was MI Nurul Iman with MIN 02 East OKU based on observations that met the criteria. Qualitative data collection techniques using observation and interviews while quantitative using a questionnaire. Quantitative data analysis techniques using calculations and simple linear regression. Based on calculations, financial literacy data obtained a value of $73 \%$ of the expected. While the entrepreneur spirit of students is $75 \%$ of what is cultivated. Furthermore, the effect of the two using simple linear regression obtained sig of $0.029<0.05$ so it can be concluded that $\mathrm{H} 0$ which reads there is no influence between financial literacy on the entrepreneur spirit of students is rejected, and $\mathrm{Ha}$ is accepted which means that there is an influence between financial literacy on the entrepreneur spirit of students. From the results of the study, it can be concluded that there is an influence of the application of financial literacy on the entrepreneur spirit of children in MI East OKU.
\end{abstract}

Keywords: financial literacy; entrepreneur spirit; Islamic primary school

\section{INTRODUCTION}

Person's economic mindset can influence behavior in the economy leading to consumptive activities or productive activities. This perspective can affect the unemployment rate which in turn will have an impact on the national economy. Behavior that tends to be consumptive based on a capitalist point of view can weaken productivity so that it has an impact on high crime rates, increased unemployment, and increased poverty rates (Akmah and Saputra, 2016: 235-236). So changing one's mindset to be productive becomes an alternative to reducing unemployment and poverty. The issue of economic literacy becomes important for everyone, especially for teenagers and children at an early age. Financial literacy is a talent but it does not mean it can grow by itself and requires guidance and training. Financial literacy in the context of formal education can be taught through education and can be linked to learning materials, for example in social studies lessons on buying and selling materials, or in other materials, for example in PKN subjects on nationality, so the 
economic value can be linked to economic values. Pancasila, namely cooperation with the spirit of cooperatives, love for domestic products, saving, and frugality (Rohmah, 2019: 85).

Economic literacy is closely related to one's economic behavior in living daily life. The importance of economic literacy is taught in early childhood because at the age of one to seven years is the initial stage for children to learn and begin to develop in behavior. Early childhood economic education is focused on children aged six to seven years. This is because children of that age already understand the function of money. In addition, children aged six and seven years in 2035 will be 22 years old in the era of bonus demographic has entered a productive age where the population explosion at that time was possible to have an impact on disaster windows or opportunity windows, thus financial literacy should be taught from an early age as a provision for children. in the future (Falikhah, 2017: 16).

Financial literacy is a process for a person to gain the ability to understand, manage and apply information to decide on financial management. The ability to process one's money or financial literacy is not only the ability to generate and earn sufficient income but the ability to manage finances properly, wisely, and appropriately is also financial or financial literacy. Managing finances has a very significant role to determine the level of welfare of a person and family. School institutions or educational institutions have a very important role to provide knowledge and understanding of financial literacy education for children. Financial literacy education is very important to be applied to children as early as possible, especially children at preschool and elementary school because with the introduction of financial literacy knowledge from an early age, children will get used to managing finances properly and correctly in the future.

The literacy that is taught will have an impact on the life to come because when entering a productive age the child can behave economically well and is no longer a burden on his parents. The hope is that early economic literacy will become a habit and then gradually become values that are carried out continuously into a culture of economic behavior. However, in Indonesia economics is taught at the earliest school level at the junior high school (SMP) level even though economics should be taught from a young age and as early as possible (Mulyadi and Trizki: 2012). Educating children in good economic behavior is that children are taught to choose or make decisions about their consumption, how to get used to behaving honestly in managing finances the context can be in the form of pocket money management and how a child is able to give reasons for what is decided related to his needs and desires because in essence Economics is a science of skills in choosing and making decisions (Yushnita, 2017: 11).

According to Rapih (2016: 14) the benefits of financial literacy a) Students have been provided with sufficient understanding, b) A comprehensive understanding of the importance of financial management c) Early introduction so that students are active in saving and behaving productively d) Cultivating the spirit of entrepreneur students. The concept of decisions in the economy is saving and productive in creating goods and services, as well as being able to read business opportunities. Entrepreneurship is an important issue in the economy of a developing nation such as the Indonesian nation. Entrepreneurship must be built consciously from an early age so that the younger generation begins to encourage it and make it a career that is able to support the welfare of the nation in the future. This is proven by the support of counseling on entrepreneurship conducted by the government with the aim that the Indonesian generation has enough knowledge and mentality to become an entrepreneur. Ready to face the business world and reduce unemployment due to the difficulty of getting a job. Children are like white paper in the future to be black or remain white depending on the education they receive. Education is Financial literacy very important to be applied to early childhood because the benefits will be felt when children are adults. So the hope is that when their children grow up they can manage their finances well and become entrepreneurs. 
Based on the initial observations made by the researcher, it was found that children in MI East OKU already have an entrepreneur spirit, such as selling snacks/food, toys, and receiving orders from friends for the items needed even though the scope is still small, that is only selling in their respective schools. MI Nurul Iman Kumpul Mulyo is a school that implements saving and sodaqoh programs on Fridays, it teaches children to live frugally and build children's character. At MIN 02 East OKU there is a school cooperative that can be a vehicle for children to develop children's entrepreneur creativity and also carry out activities to set aside pocket money for savings every day. From the background above, it is necessary to study further whether financial literacy can affect the entrepreneur spirit in children. and meet the criteria of research objectives. Research objectives 1). To find out how Financial Literacy is in children in East OKU. 2). To find out how the entrepreneur spirit in children in East OKU. 3) To determine the effect of economic literacy on the spirit of entrepreneur children in East OKU.

\section{RESEARCH METHOD}

This research is a type of research mixed method with a descriptive approach. MixedMethod is a research approach that combines qualitative research with quantitative research (Creswell, 2010:5). Meanwhile, according to Sugiyono (2011: 18). Mixed-Method is a research step by combining two approaches, namely qualitative research and quantitative research to obtain more comprehensive, valid, reliable, and objective data.

The approach mix methods aim to answer the problem formulation of how Financial Literacy in children in East OKU and how the entrepreneur spirit in children in East OKU, the first and second problem formulations can be answered through a qualitative approach and the third problem formulation is the influence of economic literacy on the entrepreneur spirit in children in East OKU can be answered through a quantitative approach. This research was conducted to find new problems that exist in the field which will then provide a new understanding for each school as an option for solving problems and also innovating programs in schools.

The population of this research is all MI students in district East OKU. The population of this study is MI in East OKU and the samples in this study are MI Kumpul Mulyo and MIN 02 East OKU by considering the criteria of financial literacy and entrepreneur spirit. Data collection techniques in this study using observation, questionnaires, and interviews. Before the instrument is given to the respondent, the researcher will test the validity and reliability first. The next stage is to test the research hypothesis, by using simple linear regression analysis to measure the influence of financial literacy on the entrepreneur spirit in children. To make it easier for researchers to analyze the data obtained by researchers using SPSS assistance.

\section{RESEARCH RESULTS AND DISCUSSION}

This study aims to: (1) Find out how the implementation of Financial Literacy education for children in MI East OKU. (2) Knowing how the spirit of entrepreneur children in MI East OKU (3) To find out how much influence financial literacy has on the entrepreneur spirit of MI children East OKU.

Samples were taken from all Islamic Madrasah in East OKU are from 2 Madrasah Ibtidaiyah that are (1) State Islamic Madrasah of MIN 02 East OKU andate Islamic Madrasah of MI Nurul Iman Kumpul Mulyo East OKU. Sampling is done through purposive sampling technique, sampling with certain considerations, namely by considering the limitations of time and learning period with an online system. The results of the study are as follows:

Based on the theory of social learning, children have had experiences about their finances learning through observation, positive or negative reinforcement, training, and 
participation, as well as giving instructions that are deliberately given by parents at home. Another impact is that the literacy or financial condition of children is not much different from the financial or financial condition of their parents (Akmal, \& Saputra: 2016). Financial literacy education in the school environment is very important, in addition to being a balancer and complement to the financial literacy education that children have received from their parents, it can also be an alternative to break the poverty chain or at least be able to minimize unemployment in the community. Therefore, children from underprivileged family backgrounds and lack of financial literacy education from their parents will also receive adequate education about financial management from the school environment. At an early age, children are at the pre-school stage as well as at the elementary school stage, individuals who are at the abstract stage or likened to a white paper who need to be given knowledge and understanding of the basics of the economy and managing finances (Mulyadi \& Trizki : 2012).

The results obtained from the literacy study, the researchers wanted to see to what extent the application of financial literacy at the Madrasah Ibtidaiyah level educational institutions in East OKU, does the financial literacy education that has been applied so far influence the entrepreneur spirit in children?. The implementation of financial literacy carried out at MIN 02 East OKU and MI Nurul Iman Kumpul Mulyo is determined based on the policies taken by stakeholders and madrasah principals, in addition to the stage of the learning process in the classroom with the education of financial literacy, and the existence of facilities that support financial literacy. Below is a series of implementation education of financial literacy carried out at MIN 02 East OKU and MI Nurul Iman Kumpul Mulyo:

Tabel 1. Implementation of Education in Financial Literacy MIS East OKU and MIN 02 East OKU

\begin{tabular}{|c|c|c|}
\hline Financial Literacy & Activities & Literacy Concepts \\
\hline Policy & $\begin{array}{l}\text { - Efforts to implement the Ministry of } \\
\text { Education and Culture's appeal related } \\
\text { to the school literacy movement } \\
\text { - Carry out entrepreneur activities } \\
\text { - There are basic competencies related to } \\
\text { financial literacy education }\end{array}$ & $\begin{array}{ll}\text { - } & \text { Obtain } \\
\text { - } & \text { Save } \\
\text { - } & \text { Spend }\end{array}$ \\
\hline $\begin{array}{l}\text { Learning stage (Learning } \\
\text { social science material on the } \\
\text { role of the economy to } \\
\text { improve life in the } \\
\text { community) }\end{array}$ & $\begin{array}{l}\text { - Students are introduced to various types } \\
\text { of economics in the surrounding } \\
\text { environment } \\
\text { - Students visit traditional markets around } \\
\text { the school } \\
\text { - Students conduct interviews with traders } \\
\text { - Students are trained to make handicrafts }\end{array}$ & $\begin{array}{ll}\text { - } & \text { Obtain } \\
\text { - } & \text { Save } \\
\text { - } & \text { Spend }\end{array}$ \\
\hline $\begin{array}{l}\text { Supporting facilities for the } \\
\text { implementation of financial } \\
\text { literacy }\end{array}$ & $\begin{array}{l}\text { - Students gain knowledge from fiction } \\
\text { and non-fiction books related to financial } \\
\text { - Students gain knowledge from financial } \\
\text { literacy learning games and videos } \\
\text { - There is a school cooperative } \\
\text { - } \quad \text { Implementation of saving in class } \\
\text { - }\end{array}$ & $\begin{array}{l}\text { - Obtain } \\
\text { - Save } \\
\text { - } \text { Spend } \\
\text { - } \text { Donate }\end{array}$ \\
\hline Follow-up & $\begin{array}{l}\text { - Students are trained for entrepreneurship } \\
\text { by making processed foods } \\
\text { - Held a bazaar at the madrasah }\end{array}$ & $\begin{array}{l}\text { - Obtain } \\
\text { - Save } \\
\text { - Spend }\end{array}$ \\
\hline
\end{tabular}

Source: Data processed by Researchers 
Looking at the table above, it can be explained that the implementation of financial literacy education in MIN 02 and MI Nurul Iman Kumpul Mulyo has been implemented well. Class-based financial literacy education is also carried out by the basic competencies and themes that have been set by the government. This basic competence (KD) is a minimum number of abilities (KM) that must be possessed by students in mastering certain subjects. The basic competencies (KD) in the low class are different from those in the high class. Basic competencies in low grades (class II and III related to financial literacy education are found in Mathematics learning. While basic competencies in high grades (grades IV and V) are found in Social Science Learning.

Application of financial literacy in MIN 02 East OKU and MI Nurul Iman Kumpul Mulyo has been implemented well. This can be seen from the learning process in the classroom. The teacher teaches financial literacy education related to the types of economics in the community. The abstract concept of financial literacy education can be transformed into concrete with the help of learning media. The media used by teachers in teaching financial literacy education, namely video media. The existence of this media can help students understand and make learning active and fun. Teachers use the field trip method by interviewing traders at the market closest to the school. The school also follows up with $\mathrm{m}$ hold bazaar activities. This bazaar activity sells the work made by students and students directly sell these products, especially for upper-class children, namely grades IV, V, and VI. The teachers and students provide a place to sell their work in the Madrasah field. The products they sell range from food, drink, and flower crafts made of cardboard, as well as plastic straws.

The implementation of financial literacy education in the classroom is adjusted to the basic competencies to be taught. These basic competencies are contained in every subject that already exists at the elementary school level. The basic competencies that contain financial literacy education are integrated with other subjects, so financial literacy education does not stand alone in certain subjects. According to the Director-General of Primary and Secondary Education (2016), the implementation of financial literacy education for students at the Madrasah Ibtidaiyah level can be done by integrating existing lessons and emphasizing practices that are adapted to financial literacy activities. Financial literacy education for students at the Madrasah Ibtidaiyah level can be found in other subjects, namely Mathematics and Social Sciences. According to Mosley [4] at the Madrasah IBtidaiyah level, the concept of financial literacy education can be found in learning Mathematics, Indonesian and Social Education lessons. This is following the fact that financial literacy education can be found in the basic competencies of students in class II (low) and class V (high class). Financial literacy education materials for class II students are integrated to mathematics lessons, while for class $\mathrm{V}$ students are integrated to social studies lessons.

Madrasah also provide facilities that support the implementation of financial literacy education, including school libraries and classroom reading corners. This is following the Guidebook for the Literacy Movement in Schools that the school library has a function, namely as a center for the management and development of knowledge and learning resources; the library can be managed by a library team that is trained in the management of literacy materials; library should be equipped with systems and applications to record visitors, and reading activities, and other literacy facilities. The availability of a variety of reading materials is included in supporting sources in the implementation of financial literacy education. The availability of varied financial reading materials can attract and motivate students to read books related to financial education. This is following research conducted by Guthrie \& Humenick (2007) that the availability of various choices of reading materials in reading activities can increase students' motivation to read. 
The existence of a school cooperative that has been implemented by Madrasah Ibtidaiyah 02 East $\mathrm{OKU}$ is also a means of supporting the implementation of financial literacy education in MIN 02 East OKU. The existence of cooperatives trains children to manage their finances in terms of spending the existing money. This is different from Madrasah Ibtidaiyah Nurul Iman which implements financial literacy education by holding a mandatory charity box that is filled every Friday. In addition, MI Nurul Iman also implements financial literacy education and holds a Madrasah bazaar which is held once a year, with the hope of fostering an entrepreneur spirit in children. Children are taught to process foodstuffs, drinks, and crafts that can be made for sale and purchase at the Madrasah bazaar. at MI Nurul Iman there is also an honesty canteen whose management system is all held by fifth-grade students accompanied by their class teacher. The honesty canteen is also a very good tool in the application of financial literacy as well as to instill an entrepreneur spirit in students.

\section{A. Financial Literacy Student}

Tabel 2. Financial Literacy MIS East OKU dan MIN 02 East OKU

\begin{tabular}{|c|c|c|c|c|c|c|c|}
\hline No & Financial Literacy & No & Financial Literacy & No & Financial Literacy & No & Financial Literacy \\
\hline 1 & 8.0 & 16 & 7.0 & 31 & 15.0 & 46 & 9.0 \\
\hline 2 & 11.0 & 17 & 7.0 & 32 & 15.0 & 47 & 12.0 \\
\hline 3 & 13.0 & 18 & 11.0 & 33 & 13.0 & 48 & 12.0 \\
\hline 4 & 13.0 & 19 & 8.0 & 34 & 8.0 & 49 & 12.0 \\
\hline 5 & 14.0 & 20 & 11.0 & 35 & 14.0 & 50 & 12.0 \\
\hline 6 & 15.0 & 21 & 9.0 & 36 & 15.0 & 51 & 10.0 \\
\hline 7 & 14.0 & 22 & 8.0 & 37 & 14.0 & 52 & 9.0 \\
\hline 8 & 11.0 & 23 & 9.0 & 38 & 12.0 & 53 & 10.0 \\
\hline 9 & 8.0 & 24 & 10.0 & 39 & 10.0 & 54 & 13.0 \\
\hline 10 & 9.0 & 25 & 10.0 & 40 & 9.0 & 55 & 13.0 \\
\hline 11 & 7.0 & 26 & 11.0 & 41 & 10.0 & 56 & 11.0 \\
\hline 12 & 8.0 & 27 & 14.0 & 42 & 9.0 & 57 & 15.0 \\
\hline 13 & 7.0 & 28 & 13.0 & 43 & 7.0 & 58 & 14.0 \\
\hline 14 & 15.0 & 29 & 12.0 & 44 & 15.0 & 59 & 13.0 \\
\hline 15 & 8.0 & 30 & 11.0 & 45 & 10.0 & 60 & 12.0 \\
\hline \multicolumn{7}{|c|}{ TOTAL: $\mathbf{6 6 5}$} \\
\hline
\end{tabular}

Source: Data processed by Researchers

If the descriptive hypothesis (first problem formulation one variable) is not formulated then data analysis is directed to answer the problem formulation, so it does not test the hypothesis. By looking at the table above, a total score of 665 is obtained. Thus the financial literacy score that can be displayed is the total score: ideal score $=665: 900=0.73=73 \%$ So the financial literacy that exists in students in MIN and MIS East OKU is 73\% than expected.

\section{B. Entrepreneur Spirit Student}

Tabel 3. Entrepreneur Spirit MIS East OKU dan MIN 02 East OKU

\begin{tabular}{|c|c|c|c|c|c|c|c|}
\hline No & $\begin{array}{c}\text { Entrepreneur } \\
\text { Spirit }\end{array}$ & No & $\begin{array}{c}\text { Entrepreneur } \\
\text { Spirit }\end{array}$ & No & $\begin{array}{c}\text { Entrepreneur } \\
\text { Spirit }\end{array}$ & No & $\begin{array}{c}\text { Entrepreneur } \\
\text { Spirit }\end{array}$ \\
\hline 1 & 11.0 & 16 & 8.0 & 31 & 11.0 & 46 & 8.0 \\
\hline 2 & 10.0 & 17 & 12.0 & 32 & 10.0 & 47 & 12.0 \\
\hline 3 & 14.0 & 18 & 11.0 & 33 & 13.0 & 48 & 12.0 \\
\hline 4 & 13.0 & 19 & 12.0 & 34 & 14.0 & 49 & 10.0 \\
\hline 5 & 14.0 & 20 & 11.0 & 35 & 13.0 & 50 & 9.0 \\
\hline 6 & 15.0 & 21 & 8.0 & 36 & 14.0 & 51 & 10.0 \\
\hline 7 & 14.0 & 22 & 9.0 & 37 & 14.0 & 52 & 13.0 \\
\hline 8 & 12.0 & 23 & 10.0 & 38 & 15.0 & 53 & 13.0 \\
\hline 9 & 9.0 & 24 & 10.0 & 39 & 14.0 & 54 & 11.0 \\
\hline 10 & 9.0 & 25 & 11.0 & 40 & 12.0 & 55 & 11.0 \\
\hline
\end{tabular}




\begin{tabular}{|l|c|c|c|c|c|c|c|}
\hline 11 & 8.0 & 26 & 11.0 & 41 & 8.0 & 56 & 11.0 \\
\hline 12 & 8.0 & 27 & 13.0 & 42 & 9.0 & 57 & 13.0 \\
\hline 13 & 15.0 & 28 & 14.0 & 43 & 15.0 & 58 & 14.0 \\
\hline 14 & 7.0 & 29 & 12.0 & 44 & 7.0 & 59 & 12.0 \\
\hline 15 & 8.0 & 30 & 10.0 & 45 & 8.0 & 60 & 10.0 \\
\hline \multicolumn{7}{|c|}{ TOTAL: $\mathbf{6 7 5}$} \\
\hline
\end{tabular}

Source: Data processed by Researchers

By looking at the table above, a total score was obtained. Thus the score of the entrepreneur spirit that can be displayed is the total score: ideal score $=675: 900=0.75=75 \%$ So the entrepreneur spirit that exists in students at MIN and MIS East OKU is $75 \%$ of what is expected.

\section{The Influence of Financial Literacy on the Spirit of Entrepreneurs Children at MI \\ 1. Normality Test}

Before calculating the effect of financial literacy on the entrepreneur spirit of students at MI Nurul Iman, first, see whether the data is normally distributed or not in the questionnaire that will be used to obtain data. The following is the output of the normality of the data for the variables of financial literacy and entrepreneur spirit.

Tabel 4. Tests of Normality

\begin{tabular}{|l|r|r|r|r|r|r|}
\hline & \multicolumn{3}{|c|}{ Kolmogorov-Smirnov $^{\mathrm{a}}$} & \multicolumn{3}{c|}{ Shapiro-Wilk } \\
\cline { 2 - 7 } & Statistic & \multicolumn{1}{c|}{ Df } & \multicolumn{1}{c|}{ Sig. } & Statistic & \multicolumn{1}{c|}{ df } & \multicolumn{1}{c|}{ Sig. } \\
\hline Financial_literacy & .114 & 60 & $\mathbf{. 0 5 1}$ & .938 & 60 & .004 \\
Entrepreneur_spirit & .111 & 60 & $\mathbf{. 0 6 3}$ & .947 & 60 & .011 \\
\hline
\end{tabular}

a. Lilliefors Significance Correction

The basis for decision making in the normality test above are:

a. If the significance value (Sig.) is greater than 0.05 , the research data is normally distributed.

b. If the significance value (Sig.) is less than 0.05 , the research data is not normally distributed.

From the table test of normality by looking at Kolmogorov Smirnov, it is known that the financial literacy variable data is 0.051 and the Entrepreneur spirit variable is 0.063 . Both data are greater than 0.05 , which means that the data is normally distributed.

2. Linearity

Furthermore, before looking for the effect, the linearity of the data is sought first as in the table:

Tabel 5. ANOVA Table

\begin{tabular}{|c|c|c|c|c|c|c|}
\hline & & $\begin{array}{l}\text { Sum of } \\
\text { Squares }\end{array}$ & Df & $\begin{array}{l}\text { Mean } \\
\text { Square }\end{array}$ & $\mathrm{F}$ & Sig. \\
\hline \multirow{5}{*}{$\begin{array}{l}\text { Entrepreneur_S } \\
\text { irit* } \\
\text { Financial_Litera } \\
\text { cy }\end{array}$} & n (Combined) & 75.002 & 8 & 9.375 & 2.041 & .060 \\
\hline & Linearity & 24.725 & 1 & 24.725 & 5.383 & .024 \\
\hline & $\begin{array}{l}\text { Deviation from } \\
\text { Linearity }\end{array}$ & 50.277 & 7 & 7.182 & 1.564 & .168 \\
\hline & Groups & 234.248 & 51 & 4.593 & & \\
\hline & & 309.250 & 59 & & & \\
\hline
\end{tabular}

Source : Data Processed by the Researcher 
Based on the significant value of the output above, the value is Deviation from Linearity 0.168 , which is greater than 0.05 , so it can be concluded that there is a significant linear relationship between the financial literacy variables and the entrepreneur spirit.

Furthermore, to determine the effect of financial literacy on the spirit of entrepreneur students, it can be calculated using simple linear regression because the data is normally distributed and has a linear relationship.

\begin{tabular}{|c|c|c|c|c|c|c|}
\hline \multirow{2}{*}{\multicolumn{2}{|c|}{ Model }} & \multicolumn{2}{|c|}{ Unstandardized Coefficients } & $\begin{array}{c}\text { Standardized } \\
\text { Coefficients }\end{array}$ & \multirow[b]{2}{*}{$\mathrm{T}$} & \multirow[b]{2}{*}{ Sig. } \\
\hline & & B & Std. Error & Beta & & \\
\hline \multirow[t]{2}{*}{1} & (Constant) & 8.418 & 1.294 & & 6.507 & .000 \\
\hline & Financial_Literacy & .256 & .114 & .283 & 2.245 & .029 \\
\hline
\end{tabular}

a. Dependent Variable: Entrepreneur Spirit

The hypothesis proposed in this study is

$\mathrm{H}_{0}=$ there is no influence between literacy financial on the spirit of entrepreneur students $\mathrm{H}_{\mathrm{a}}=$ there is an influence between literacy financial on the spirit of entrepreneur students

Basic decision making is simple linear regression test by comparing the value of sig with 0.05

a. If the significance value (Sig.) is less than 0.05 then there is an influence between financial literacy on the entrepreneur spirit.

b. If the significance value (Sig.) is greater than 0.05 , there is no influence between financial literacy and the entrepreneur spirit.

Based on this output, it is known that the significance value (Sig.) of 0.029 is smaller than 0.05 , so it can be concluded that $\mathrm{H}_{0}$ which reads there is no effect between Financial literacy on the entrepreneur spirit of students is rejected, and $\mathrm{H}_{\mathrm{a}}$ is accepted, which means that there is an influence between financial literacy on the entrepreneur spirit of students. It can be concluded that there is an effect of applying financial literacy to the entrepreneur spirit in children.

Financial literacy is a process for a person to gain the ability to understand, manage and apply information to decide on financial management. A person's financial ability is not only the ability to earn sufficient income but also the ability to manage finances properly, wisely, and appropriately. Financial management has a very significant role in determining the level of welfare of a person and family. The role of schools is also very important to provide knowledge about financial literacy education for children. Financial literacy education is very important to be applied to children as early as possible, especially children at preschool and elementary school because with the introduction of financial literacy knowledge from an early age, children will get used to managing finances properly and correctly in the future. This has also encouraged many educational institutions that have implemented literacy education in their schools, none other than the Madrasah Ibtidaiyah level in East OKU, which have also implemented literacy education. The benefits of financial literacy 1) Students have been provided with sufficient understanding of the importance of financial management, 2) Comprehensive understanding of the importance of financial management 3) Early introduction so that students are active in saving and behaving productively 4) Cultivating the entrepreneur spirit of students Entrepreneurship must be built consciously from an early age, thus the younger generation began to encourage it and make it a career that turned out to be able to support the welfare of the nation in the future. This is 
proven by the support of counseling about entrepreneurship conducted by the government with the aim that the Indonesian generation has enough knowledge and mentality to become an entrepreneur. Children who know the world of entrepreneurship from an early age will find benefits for their future provisions.

Entrepreneurship learning in children from an early age does not necessarily exist but requires gradual training. It can be started from small things in children's daily activities and teach children to manage money well, that the practice is not only how to spend, but also save and earn money.

\section{CONCLUSION}

The results of the research objectives are: (1) the application of financial literacy in both schools, that are MIN 02 East OKU and MI Nurul Iman Kumpul Mulyo has been implemented well, as evidenced by the existence of supporting facilities in the application of financial literacy, including saving activities which have been implemented in both schools, the existence of school cooperatives that are implemented in MIN 02 East OKU, the filling of charity boxes every Friday which is required for students at MI Nurul Iman, in addition to the integration of subjects contained in the Basic Competencies in Subject social studies lessons. (2) entrepreneur spirit in children. (3) There is an influence between financial literacy on the entrepreneur spirit of students. It can be concluded that there is an effect of applying financial literacy to the entrepreneur spirit in children.

\section{REFERENCES}

Akmal, H., \& Saputra, Y. E. (2016). Analisis tingkat literasi keuangan. JEBI (Jurnal Ekonomi Dan Bisnis Islam), 1(2), 235-244.

Arikunto, S. 2013. Prosedur Penelitian: Suatu Pendekatan Praktik. Jakarta: Rineka Cipta.

Creswell, J. W. (2010). Research design: pendekatan kualitatif, kuantitatif, dan mixed. Yogjakarta: PT Pustaka Pelajar.

Falikhah, N. (2017). Bonus Demografi Peluang dan Tantangan Bagi Indonesia. Alhadharah: Jurnal Ilmu Dakwah, 16(32).

Kemdikbud, 2016. Satgas Gerakan Literasi Sekolah, "Menumbuhkan Budaya Literasi di Sekolah", Buku : Saku Gerakan Literasi Sekolah

Krishna, A., Sari, M., \& Rofaida R. 2010. Analisis Tingkat Literasi Keuangan di Kalangan Mahasiswa dan Faktor-faktor yang Mempengaruhinya-survey pada mahasiswa Universitas Pendidikan Indonesia.

Mulyadi, S., \& Trizki, L. (2012). Financial Parenting: Menjadikan Anak Cerdas dan Cermat Mengelola Uang. Noura Books.

Mulyadi, Seto. 2007. Home Schooling Keluarga Kak Seto, Bandung: Kaifa.

Nurhafizah. 2014. Bimbingan Awal Kewirausahaan pada Anak Usia Dini. Jurnal Konseling dan Pendidikan, Volume 6, No 2, 2018, Hlm 62-66.

Otoritas Jasa Keuangan . (2013). Strategi Nasional Literasi Keuangan Indonesia. 03 Juli 2019. www.ojk.go.id

Rapih, S. (2016). Pendidikan Literasi Keuangan Pada Anak: Mengapa dan Bagaimana?. Scholaria: Jurnal Pendidikan dan Kebudayaan, 6(2), 14-28.

Remund, David L. 2010. Financial Literacy Explicated: The Case for a Clearer Definition in an Increasingly Complex Economy. The Journal of Consumer Affairs, 44 (2), 276-295.

Reski, N., Taufik, T., \& Ifdil, I., 2017. Konsep Diri dan Kedisiplinan Belajar Siswa. Jurnal IICET. Vol. 3. No. 07.

Rohmah, M. (2019). INTERNALISASI NILAI-NILAI PANCASILA MELALUI PENDIDIKAN EKONOMI. UTILITY: Jurnal Ilmiah Pendidikan Dan Ekonomi, 3(2), 85-94. 
Sina, Peter Garlans. 2012. Analisis Literasi Ekonomi. Jurnal Ecnomia, volume 8, No.2, Oktober 2012

Sina. 2014. Financial Efficacy dan Financial Satisfaction : ditinjau dari perbedaan Gender.Jurnal Manajemen. 12 (2), 173-184.

Sugiyono. 2017. Metode Penelitian Kuantitatif, Kualitatif, dan R\&D. Bandung : Alfabeta, $\mathrm{CV}$.

Sukardi. 2011. Metodologi Penelitian Pendidikan Kompetensi dan Praktiknya. Jakarta: PT Bumi Aksara

Yushita, A. N. (2017). Pentingnya literasi keuangan bagi pengelolaan keuangan pribadi. Nominal: Barometer Riset Akuntansi dan Manajemen, 6(1), 11-26. 